\title{
Towards a conceptual history of the present: democracy, rights, and freedom in the recent Catalan conflict
}

\author{
Peter Wagner
}

Catalan Institute for Research and Advanced Studies (ICREA); University of Barcelona (UB); and Ural Federal University (UrFU), Ekaterinburg

\begin{abstract}
Reinhart Koselleck showed that the decades around 1800 witnessed a major transformation of political language. Around 1800, the horizon of expectations gained distance from the space of the experiences that human beings were making, and thus possibilities for the future opened up widely. In particular, the future would be the time during which "peoples" would gain their capacity for self-determination, called popular sovereignty. This would occur in two particular versions that crystallized in the course of the nineteenth century, namely as "nations" that would unify or liberate themselves from monarchical and/or imperial domination to form the polities proper to them, or as a "class" that embodied the universal interest of humankind and would assert itself in a second revolution, following up on the French Revolution. Political concepts acquired during that period the meaning that they still had in the late twentieth century, i.e., the time when Koselleck developed his approch to the history of concepts, but they may be challenged in the present, and with them the entire self-understanding of modern polities.

The recent Catalan conflict serves to better understand this challenge. "People" and "nation" are there used in ways that are reminiscent of this politico-conceptual tradition, but in a highly ambiguous way. On the one hand, they are employed in exactly their historical meaning: the Catalan people and nation are seen to finally fulfilling their historical role of reaching political selfdetermination. On the other hand, these concepts are re-deployed to place them in the current context of existing democratic commitments and institutions as well as high interdependence between polities, all the while claiming that Catalan independence opens up a new normative horizon of democracy, rights, and freedom. This article will try to show that this undeclared ambiguity is characteristic of our current situation in general. This is a situation in which the historically created political concepts have sedimented in institutions, thus appear to have "consolidated" and moved beyond their historicity. At the same time, they remain impregnated with particular historical experiences that can be re-interpreted to be mobilized in political struggles of the present. To assess the validity and acceptability of any such re-interpretation requires explicit reflection about the persistence of historicity in political concepts.
\end{abstract}

Keywords: Catalonia, conceptual history, democracy, freedom, historicity, rights, selfdetermination, Spain

Hegel remarked somewhere that all great world-historic facts and persons occur, so to speak, twice. He forgot to add: the first time as tragedy, the second time as farce.

Karl Marx

George Orwell often came to mind during the autumn of 2017 after the Catalan government and parliament had violated both the Spanish and the Catalan constitution as well as their own procedures between the $6^{\text {th }}$ and $8^{\text {th }}$ of September and the Spanish government had ordered the suppression of the illegal referendum on Catalan independence by police force on the $1^{\text {st }}$ of October. 
This was so for two very different reasons and publications. First, one was reminded of Orwell's novel 1984 (Orwell 1949) because well-known concepts such as democracy, rights and freedom suddenly appeared posted all across the streets of Barcelona but it had become very difficult, if not outright impossible, to understand them. Their meaning had been changed by a powerful sociopolitical force, and the new meaning was to be impressed on the citizens by the sheer amount and omnipresence of propaganda. ${ }^{1}$ Secondly, Orwell's account of his experience during the Spanish Civil War, Homage to Catalonia (Orwell 1938), was evoked in an ambiguous way. On the one hand, one could feel the impact the reception of this book had had, in particular the late reception long after the Second World War, because across Europe, and beyond, it contributed to making it easy to see the current events as another chapter in the political struggle of a freedom-loving people against oppression. For those who took the book again into their hands, on the other hand, it regained significance because it showed how misplaced and misguided political energy can cause enormous harm.

\section{The temporality of political concepts}

The Catalan crisis in Spain is not over at the time of writing (and it will have evolved further at the time of publication of this essay). It is rather safe to say, though, that it will not have the worldhistorical significance that the proponents of Catalan independence try to endow it with and that political interpreters such as Karl Marx have always been looking for. Even though the conflict is not exemplary, however, it can be seen as symptomatic for the political condition of our time. By mobilizing central political concepts for its case, the movement for Catalan independence has intended to give its claims an aura of self-evidence. This attempt has largely failed. What the movement in fact did, though, was to show that these concepts do not have the stability and obviousness that had widely been taken for granted, at least in Europe, both in public debate and in much of scholarly discussion.

What is at stake, to speak very abstractly to start with, is the relation between historicity and conceptuality in politics. Politics is concerned with setting the rules for the life in common; thus, all political concepts are collective concepts. This is true even for concepts that can be seen to mostly refer to individuals, such as right and freedom, because they necessarily imply a relation to other rights-holders and other free persons. Collectivities, in turn, such as peoples, nations or societies, may be theorized abstractly, but they always have a historical existence. This is to say that they do not exist unchangeably in any political sense. In other words, any political claim in the present needs to address the tension between historicity and conceptuality that the use of political concepts always implies. The Catalan conflict lends itself to a broader reflection about this tension because the tension became very explicit in the course of the events.

Reinhart Koselleck showed that the decades around 1800 witnessed a major transformation of political language. It was during that period, he found, that political concepts acquired the meaning that they still had at the time he developed his approch to the history of concepts, namely the late twentieth century. Around 1800, the horizon of expectations separated from the space of the experiences that human beings were making, and thus possibilities for the future opened up widely. In particular, the future would be the time during which "peoples" would gain their capacity for self-determination, called popular sovereignty. This would occur in two particular versions that crystallized in the course of the nineteenth century, namely as "nations" that would unify or liberate themselves from monarchical and/or imperial domination to form the polities proper to them, or as a

11984 can be interpreted as a portrait of the totalitarianisms that Orwell experienced in his life-time. To avoid misunderstandings, it should be stated that my reference to Orwell's novel does not entail that I see the Catalan independence movement as totalitarian - a much more differentiated view is required, as will hopefully become clear in the course of my analysis. 
"class" that embodied the universal interest of humankind and would assert itself in a second revolution, following up on the French Revolution. In the Catalan conflict, "people" and "nation" are used in ways that are reminiscent of this politico-conceptual tradition ("class" appears in an undercurrent, but is not central to the conflict). But they are used in a highly ambiguous way. On the one hand, they are employed in exactly their historical meaning: the Catalan people and nation are finally fulfilling their historical role of reaching political self-determination. On the other hand, these concepts are re-deployed to place them in the current context of existing democratic commitments and institutions as well as high interdependence between polities, all the while claiming that Catalan independence opens up a new normative horizon of democracy, rights and freedom. This article will try to show that this undeclared ambiguity is characteristic of our current situation in general. This is a situation in which the historically created political concepts have sedimented in institutions, thus appear to have "consolidated" and moved beyond their historicity. At the same time, they remain impregnated with particular historical experiences that can be reinterpreted to be mobilized in political struggles of the present. To assess the validity and acceptability of any such re-interpretation requires explicit reflection about the persistence of historicity in political concepts. In contrast, as will be shown, the Catalan movement avoids such reflection and works with the confusion of the meanings to reach its objectives, at times because the ambiguity remains unrecognized, but at times also deliberately so.

In what follows, I will first elucidate the tension between conceptuality and historicity by discussing the conflict in established conceptual terms that have been used in the situation, even though they do not apply very well. This section also provides some brief information about the background of the conflict and the recent occurrences (for more detail and a somewhat different interpretation, see Gamper 2018, in this issue). Subsequently, the question of historicity will be explored by showing how the actors have tried to situate the occurrences in historical time. Against that background, vice versa, the attempts to give abstract political concepts a new meaning will be retraced, a meaning that is new and at the same time presented as self-evident. In the following step, the question of political temporality will be further discussed by using the distinction, made prominent by Cornelius Castoriadis, between the instituting and the instituted. After all, the main claim of the opponents of independence has been that freedom and democracy have already been well instituted in Spain, whereas proponents have argued that a creative process of instituting them is required.

The analysis is based on the insight that major political change is often to a considerable extent a matter of re-interpretation of the collective situation one finds oneself in. This insight emerges in conjunction of seeing human beings as "self-interpreting animals" (Charles Taylor) in general and of observing major changes in political language at certain historical moments. The historiography of concepts as developed by Reinhart Koselleck, Michel Foucault, and Quentin Skinner in different and distinct ways has provided ample evidence for major historical transformations of political concepts (Wagner 2003), but little has been done hitherto to show that human agency is at work in the present to change the conceptual basis of existing political self-understandings - or in other words, to develop a conceptual history of the present time (see recently Wagner 2018). In this light, what follows is a study of an attempt at conceptual re-interpretation to bring a political transformation about. It will focus on the use of concepts and, in particular, on ways of locating them in historical time. Having said this, it should be added that this study only says something at its margins on two questions that emerge in its course, namely: What are the motivations, what is the political energy that makes people get involved in major work at conceptual re-interpretation? And: What are the consequences of a successful re-interpretation or, more appropriate in this case, of the de-stabilizing of the existing interpretation? The article will conclude with some reflection on these aspects of the conflict that the conceptual analysis itself fails to reach.

\section{A note on terminology and sources}


Before proceeding, a note on terminology and sources is necessary. Most of the Spanish and Catalan terms used in the conflict lend themselves to straightforward adaptation in English, but choices and connotations need to be made explicit. When referring to those actors claiming independence for Catalonia, I will use the term "independentists", which is also a self-description and avoids the - often, though not always - negative connotations of "separatism" and "secessionism". "Independentism", it is important to underline, is not synonymous with "Catalanism". The latter term applies generally to all positions that claim that Catalonia is a somewhat particular political subject, a view-point that is widely shared in Catalonia as well as to some extent across Spain and does not necessarily imply a claim to independence. Indeed, it is often argued that the broader approch of Catalanism has been weakened or destroyed by the polarization brought about by independentism.

In turn, I will prefer the term "constitutionalists" for those actors who argue for a continued integration of Catalonia into Spain, and avoid "unionism", which is common as a term for the Northern Irish question, but has pejorative connotations in Spain. Focussing on conceptual history and its implications, this essay will not go into the details of the various political positions. It should also be underlined that the polarization between independentism and constitutionalism is itself a product of the conflict over the past six years. Debates and positions were much more nuanced before, and the rather neat portrait provided in this article would not have been adequate even a decade ago.

Four further terms may just be noted, because they occur in the debates, and readers who consult other sources might find them missing or undervalued here: Comunidad autónoma or just autonomia, "autonomy", is the term used in the Spanish Constitution for the units of territorial organisation and their self-government. It expresses the intention of the constitution-builders to give post-Franco Spain a somewhat decentralized institutional structure. Even though the special status of the Basque Country, Catalonia, and Galicia was recognized in the same move, the competences of the autonomias were never precisely spelt out, thus opening the interpretative space for the current conceptual conflict. Autonomía, thus, is currently in the first instance a juridical-descriptive term for the status quo; however, independentists claim that this model has failed and have started to use the term negatively, referring to the undesirable continuity of the status quo. In turn, "federalism" is a term that is applied to those, and in part also by them, who argue that the current degree of decentralization in Spain needs to be made more explicit and the rights of the autonomous communities be secured through reform of the Spanish Constitution. This strategy is also referred to as "the third way", that is, beyond independentism and constitutionalism.

Thirdly, the term "nationalism" is used in Spain predominantly for the movements seeking greater self-determination for Catalonia and the Basque Country. In this sense, one speaks of Catalan and Basque "nationalist" parties in the Spanish parliament. However, it can also be employed for Spanish "nationalism", defending the unity of the Spanish polity and often also a greater degree of centralism. Only to avoid confusion, the term will not be used in the following. Clearly, though, there are features of the Catalan independence movement and of the reaction against it that could appropriately be described under the general concept of nationalism. One can say, more strongly, that a temporary outcome of the conflict has been to give rise to nationalist sentiments and expressions that had been weak or absent in prior public political debate in Spain. For instance, Spain had not yet witnessed the emergence of any significant "new right" movement until now, in contrast to many other European polities. This leads over, finally, to the question of "populism". With its reference to "the Catalan people" as the source of authority and sovereignty, the independence movement could arguably be called populist. Largely, though, this term is absent from self-description, most likely because of its predominantly pejorative connotations. In Spain overall, the political party Podemos, created after the so-called indignados movement of 2011, 
referred positively to populism, envisaging a kind of left-wing version of it (see Booth and Baert 2018), but also appears to be withdrawing from its use. Given the very limited self-use by the actors involved, this article will not employ this concept either (for a discussion of "democratic populism" in Catalonia, see Gamper 2018).

This essay is based on a great variety of primary sources. It includes close participant observation as resident, but not citizen, of Catalonia and Spain, including numerous political conversations with activists, citizens and observers. Furthermore, it uses newspaper accounts and commentary, in particular from El País, a Madrid-based left-liberal daily, La Vanguardia, a Barcelona-based daily with roots in the nineteenth century, now published in both Spanish and Catalan, and Ara, a rather new Catalan newspaper close to the case of independentism. From September 2017, the referendum campaign and the subsequent Catalan elections have generated an enormous amount of political propaganda, including election publicity. After the turn of events due to the move towards a unilateral decalaration of independence by the Catalan government and subsequent intervention into the Catalan autonomy by the Spanish government at the end of October 2017, numerous books have been published on the occurrences. A first high-point was reached with Saint George's Day, 23 April 2017, Day of the Book in Catalonia since $1929,{ }^{2}$ featuring accounts of the experiences by participants and even including books that claim to explain the events to children, and a second one on the occasion of the first anniversary of the September/October events, then seeing a greater number of more reflective works emerging. In an incomplete overview, Babelia, the literary supplement of El País, of 22 September 2018 mentioned not less than twenty just-published books on the Catalan conflict. Furthermore, friends and colleagues have directed me to relevant internet sites. ${ }^{3}$ A form of "sociological interventionism" (Alain Touraine) has been practiced by initiating an email discussion among both residents of Catalonia and international observers and intervening in public debate as well as in a workshop on the uses of history in this conflict, organized by Gerard Rosich at the University of Barcelona in February 2018.

In the following account, direct references will mostly be limited to show and analyze the actual use of political concepts in the Catalan conflict. This means, first, that references to the broader historical, cultural, social, political and economic contexts will be kept to a minimum, even though these contexts will be referred to when interpreting such use of concepts. For readers who want to deepen their knowledge of these contexts, the work by Lola García (2018), a very well informed and crafted background account by a journalist, and some of the contributions to Joaquim Coll et al. (2018), very nuanced despite being written from a predominantly constitutionalist perspective, are useful (in Spanish) as well as the somewhat contrasting interpretation by Daniel Gamper (2018) in this issue. ${ }^{4}$ Most of the references that are made, second, are to texts that are interventions into the conflict, due to the fact that what is analyzed here is a political struggle over interpretations rather than a conceptual debate at some distance from political struggle. What was at stake was to gain a "position of conceptual control over the debate" (Bassets 2018, 160, with reference to Gramsci's notion of hegemony). Some more "academic" contributions exist, and a few references to them will be made, but even those are visibly part of the struggle. In that sense, one purpose of the following analysis also is to elevate the level of conceptual debate by gaining some reflexive distance to the battle by means of concepts that happened in Catalonia over the last year. ${ }^{5}$

2 And since 1995, International Day of the Book, declared by UNESCO.

3 A special thanks is due to Carlos Valera who pointed me to sources I am unlikely to have found on my own. My thanks go to Johann Arnason and two reviewers for Social Science Information for comments on an earlier version of this article.

4 Some access to the debates in English is provided by the websites https://opendemocracy.net, generally devoted to widen public debate, and https://voicesofspain.com, of which it must be born in mind that its aim is to provide a counter-weight to what is seen as predominantly pro-independentism reporting outside Spain.

5 Conceptual clarifications as proposed here will not easily make partisan interpretations disappear or even converge. Nelson Mandela, former president of South Africa, was considered a terrorist by Western governments before the African National Congress came to power, whereas he was then seen by others, and is now so more widely, as a 


\section{The occurrences and their concepts: national liberation or coup d'état?}

Since the Napoleonic Wars and the short-lived, rather liberal Constitution of Cádiz of 1812, Spanish political history ran largely in parallel as well as entangled ways with other West European countries (Junco and Shubert 2018). But three - rather consecutive and interlinked - elements stand out that make the Spanish political experience more specific: First, Spain was an empire that had created settler colonies, predominantly in Latin America, most of which became independent in the early nineteenth century but retained strong cultural links with Spain. Secondly, the defeat in the Spanish-American War of 1898 led to a deep crisis in the Spanish political self-understanding, including a polarization between Europe-oriented liberal groups and imperial-nostalgic conservative groups. Thirdly, the mid-twentieth-century dictatorship of Francisco Franco (1939-75, following the Civil War of 1936-9) was more long-lasting than the authoritarian or even totalitarian regimes in other parts of West and West Central Europe, with the exception of Portugal.

Like other European countries, Spain is composed of various territories with different historical origins and experiences of self-government, the current autonomous community of Catalonia being one of them. The precise nature of the political order with regard to the integration of the territories was an item of dispute on various occasions, again not unlike in other European countries. However, the three specificities mentioned above provided interpretative resources for the Catalanist claim to greater self-government: First, the settler-colonial history permitted Catalanists to present their case as one of liberation from imperial domination, following the example of the Latin American declarations of independence. This reference is reflected in the estelada ("starred [flag]"), the symbolic flag of the independentist movement containing a star in a triangle inspired by the Cuban flag. Secondly, the polarization between liberal and clerical-conservative political forces has allowed current Catalanists to present themselves as a progressive force of history. This positioning ignores the fact that Catalanism stretches all across the political spectrum, from the extreme left to view-points close to fascism. Today, it is used in a watered-down but nevertheless widely appealing opposition between the project of a "Catalan republic" as opposed to the Spanish monarchy. Thirdly, the long and rather recent history of dictatorship permits the imaginary creation of a never-changing authoritarian Spain that oppresses Catalonia. This imaginary emphasizes, for instance, the Francoist prohibition of speaking Catalan in public, while downplaying the fact that the Civil War was a war across Spain and not between Spain and Catalonia.

Catalanism, as the striving for the recognition of Catalonia as a particular political subject, dates back to at least the late nineteenth century. In most of its versions, though, it aimed at such recognition within the Spanish polity. Independentism has always been a minority opinion, never coming close to win absolute majority support in elections, referenda, or even opinion polls. This changed only in recent years, due to two main reasons, as most observers agree. First, a new Catalan constitution (Estatut d'Autonomia) was elaborated during the short period in which the Socialist Party occupied government positions both in Catalonia and in Spain. It was approved by the Catalan parliament, by both houses of the Spanish parliament and by a referendum in Catalonia and went into force in 2006. However, the then opposition party in Spain, the Popular Party, had it checked by the Constitutional Court, which declared sections of it unconstitutional in 2010. With the onset of the financial crisis after 2010, secondly, the then centre-right Catalanist government of Catalonia introduced severe austerity measures, as indeed also did the Spanish government. The Catalan government, however, tried to shift the responsibility to the central government by asking

freedom fighter. However, conceptual reflections may at least clarify the reasons for disagreement, or so one should hope. Doubts arise, though, because independentists make wide use of largely misplaced comparisons with what they claim to be related cases of oppression, including Mandela or the Armenian genocide, thus undermining reasonable discussion. 
unsuccessfully for a reconsideration of the territorial distribution of tax revenue and subsequently claiming that Catalonia is robbed by Spain of some of the wealth it generates. From this moment, the then main Catalanist political alliance, Convergència i Unió (CiU), turned independentist and started "the process", which was the name given to the political project of creating an independent Catalan state.

This is, in due brevity, the background to the occurrences on 6-8 September and 1 October 2017 mentioned at the outset. The brief description was meant to show both the long-term persistence of the "Catalan question" and its very recent radicalization. This radicalization led to a polarization of interpretations, which is of core interest here. Using the historical elements mentioned above, independentists presented "the process" as a struggle for national liberation. The main occurrence in their account is the police repression of the mobilization of Catalans in support of the "referendum" on the $1^{\text {st }}$ of October. The attempt to endow this date with high significance goes as far as renaming public squares after this event. ${ }^{6}$ In contrast, constitutionalists interpret the occurrences as a coup d'état, as the attempt of a minority to seize state institutions and use them illegally for their political agenda. In their account, the key events are those of the $6^{\text {th }}$ to $8^{\text {th }}$ of September in the Catalan parliament. Significantly, these dates are barely mentioned in the accounts of the independentists, whereas 1 October, in turn, occurs in the constitutionalist accounts only as the inevitable consequence of 6-8 September.

National liberation and coup d'état are concepts that are at hand. Even though they are not entirely well defined, we all know occurrences to which they apply rather unproblematically. But precisely because we know such occurrences, considerable doubt arises about whether they are quite sufficient to understand the recent Catalan situation.

National liberation is the exit of a nation from domination by a foreign power, mostly within a colonial or imperial setting. The concept has been widely used for the struggles against colonial domination, such as in Africa during the 1950s and 1960s, but also for earlier occurrences, such as the Greek struggle against domination within the Ottoman Empire. As we have seen, the discourse of independentism emphasizes apparent similarities, thus claiming that the Catalans are a nation that has been oppressed within the Spanish Empire and now aims at liberation by setting up an independent state. However, the integration of the territory of current Catalonia into the Spanish polity happened through personal union of royal families, not through conquest and occupation. And while it is true that Catalan self-government was diminished after the War of Spanish Succession in 1714, this measure is better understood as part of centralization attempts of European absolutism than as subjection of a people. Furthermore, degrees of self-government were restored, even though with interruptions, at various occasions during the nineteenth and twentieth centuries. This happened in particular during more democratic periods, thus at moments when the opinion of the people counts. This conception of Catalan self-government within a democratic Spanish polity was last overwhelmingly confirmed when Catalan voters approved of the Spanish Constitution of 1978 with a very high approval rate, indeed higher than the Spanish average (95.15\% as compared to $91.81 \%$, with participation of two thirds of the citizens).

Thus, the interpretation of the independence movement as a struggle for national liberation generates significant doubts. It is at the last mentioned element, the approval of the Spanish Constitution, that the counter-interpretation of the events as a coup d'état sets in. In this account, Spain is a stable democracy with clearly developed, both legal and legitimate institutions and

6 There is an irony in the fact that the $1^{\text {st }}$ of October - of 1939 - was also the day in which Franco became head of the Spanish state and was celebrated during his dictatorship as the Day of the Caudillo, as it was commonly known. Just for illustration: After the fall of the Berlin Wall on 9 November 1989, it was explicitly ruled out in Germany to celebrate this date in future, because it is also the date of numerous other significant occurrences, such as the November Revolution of 1919, Adolf Hitler's attempted coup d'état in 1923, and the progroms againist Jews in 1938 . 
procedures. These procedures were grossly and intentionally violated by the Catalan government in September 2017 by using its slim parliamentary majority to vote on a bill about a referendum on independence and on a bill entitling the government to pursue independence in case the referendum outcome warrants this. ${ }^{7}$ Both of these bills were unconstitutional violating both the Spanish Constitution and the Estatut of Catalonia, as confirmed by the Constitutional Court shortly after. Furthermore, the parliamentary votes also violated the rights of the opposition in parliament. In the aftermath of the votes, Catalan public institutions such as statistical services, media, schools and the police were used to organize the referendum on 1 October that had been declared illegal. Broadly, these actions qualify as a coup d'état, namely the illegal seizure of the state by an elite group.

Nevertheless doubts remain for this interpretation as well. First of all, it was not the whole state that was object of the seizure, but only the territorial institutions of a part of it. Furthermore, the subject of the seizure was a territorial government that was democratically elected. It was even elected for the explicit purpose of pursuing independence, as was made clear in the campaign for the Catalan elections of September 2015, which led to the government with Carles Puigdemont as president. While without doubt acting illegally, the government was thus provided with some legitimacy. Finally, one is inclined to associate a coup d'état with some degree of violence or at least coercion. The use of violence is indeed part of the definition of "rebellion", for which some independentists now stand on trial, in the Spanish legal code. But the question if and what kind of violence has been used is still under contest and investigation. ${ }^{8}$ A central claim of the independence movement is to act only democratically and non-violently. According to the common understanding of a coup d'état, one would indeed expect insurgents to occupy centres of power against the resistance of the rightful holders of such power. But the independentists were already holding significant power centres, thus did not need to occupy them: the Catalan government, the majority of the parliament, the Catalan police force, the public broadcasting stations, etc. When pursuing courses of action that were declared illegal, thus, they rather drove Spanish institutions to use force and violence against them than using violence themselves.

As a consequence, a figure of speech emerged in which a difference is noted between that which something is and that as which it appears. Some would say the actions of September 2017 were a coup d'état, but did not appear as such because of the absence of violence by the insurgents. Or, to the contrary, some would say the actions were an exercise of democracy, but did not appear as such because the definition of the democratic collectivity was not in the hands of those who wanted to exercize democracy. In this regard, one has spoken of a "postmodern coup", as a phenomenon that is not that as which it appears, and has deliberately been designed to appear as something different from what it is (Gascón 2018).

Even though the events seem to fit the definition of coup d'état somewhat more than the one of national liberation, the doubts are so considerable that further investigation is required. Not least, one will need to understand why rather many Catalans as well as some outside observers come to interpret the events as being closer to the latter than the former. Thus, we need to take a closer look at how both independentists and constitutionalists argue the cases for their respective interpretations. In a first step, we will do so by seeing how they situate the occurrences more precisely in historical time. In the subsequent step, we will then show to what reconsiderations of basic political concepts such temporal situating leads.

\section{Historicity: how to situate occurrences in historical time}

7 Parties favouring independence then had a majority of seats but not of votes, due to an electoral system that favours rural regions. The same situation was reproduced after the elections of December 2017.

8 In a highly contested verdict, a German regional court denied the request of the Spanish Supreme Court to extradite Puigdemont to Spain for rebellion, but granted the request only with regard to the minor crime of embezzlement of public funds. 
The relation between the two contending parties is asymmetric for many reasons, but in particular with regard to the view of historical time and the current moment. The independentists aim at major institutional change, whereas their opponents are basically satisfied with the status quo (the broader significance of this difference will be discussed below). This means that the former need a view on the ongoing dynamics and direction of historical change, including the expectations for the future, whereas the latter only need to provide reasons why the present is largely satisfactory. This difference shows clearly in the multiple efforts independentists make to situate themselves and their project in history. Three strategies stand out from the debates:

The first and arguably the most conventional one is a form of evolutionism. Very much based in early-nineteenth-century European thought, though largely without acknowledging this, this view sees human social life as organized in nations and human history as a history of nation-building through which every nation finds its self-expression and contributes its share to the diversity of humanity. The Catalonia comes late to accomplish this mission, but it has now reached this point. This way of reasoning is rooted in an abstract politico-juridical concept of the nation as a source of sovereignty, but its use is often connected with an evolutionist understanding of nation-building. One example are newspaper editorials that claim that the independence movement will succeed in the end because it marches with history. Another one are conversations in which independentists point out to Chilean or Greek interlocutors that the latter already have accomplished what Catalonia still needs to accomplish. But though such evolutionism is pervasive in everyday communications, it figures much less in formal political debate, in which the politico-juridical use prevails. This discrepancy between an allegedly timeless politico-theoretical concept of nationhood and a historico-evolutionist understanding of nation-building is significant because an explicit commitment to the latter would make the independentists' case open to all the existing criticism of historical nation-building projects and their consequences. In turn, the former is in contradiction with the terms used in the Spanish Constitution, which sees Catalonia as a "nationality" within the nation of Spain rather than as a nation. ${ }^{9}$ Thus, independentism cannot easily base itself on either the one or the other of the understandings of the concept, but needs to mobilize both at the same time to be convincing. This is the first example of the conceptual ambiguity, or tension, of which we will encounter more in the course of the analysis.

Secondly, independentism also employs a form of messianism, which operates with the notion of a coming rupture in time, thus also enters in tension with evolutionism. One could expect the evolutionism to be more widespread among the more conservative supporters, while the messianism would be situated on the left of independentism. However, the situation is not so clear-cut. During the campaign for the elections to the Catalan parliament in 2012, the lead candidate of the centreright Convergéncia i Unió and incumbent president of Catalonia, Artur Mas, was presented with wide open arms, as if he were showing the electorate the promised land right in front of him. This was immediately after he had made the turn from the time-honoured and quite effective Catalanism of CiU towards independentism and had announced these elections under that heading. On the side of the left, messianism was less a picture, more a slogan. During the autumn months of 2017, areas of Barcelona were full with posters announcing what the future independent Catalonia will be: a republic, feminist, socialist, ecological, ... Everything desirable, from the point of view of the claimants, would immediately be realized once independence was reached. Both kinds of posters expressed a strong separation of the horizon of expectations from the space of experience. Underlying these expectations is a way of thinking reminiscent of the late eighteenth-century Enlightenment: then, the supposedly imminent "exit from self-incurred immaturity" (Immanuel Kant) was seen as unleashing an unstoppable dynamics of progress in the history of humankind (see recently Wagner 2016). Now, similarly, all evils in current Catalan society are attributed to Spanish

9 This is one point of contention with the Spanish Constitution and the 2010 verdict of the Constitutional Court against sections of the Estatut. 
domination. Once that domination disappears, therefore, a sudden transformation towards an essentially good and harmonious society will occur.

In contrast to the late-Enlightenment situation, the current expectations can be called messianic, because they look towards an imminent event like the arrival of a saviour from all sins and misery. That they are ill-founded is easy to see, and this for two only apparently contradictory reasons. On the one hand, current Catalonia is integrated into a capitalist world economy, using the amount of energy and other planetary resources typical of a highly industrialized and traffic-intensive economy and way of living, and has its share of male domination and gender inequality. Furthermore, conservative and business-friendly political forces occupy a considerable part of the political spectrum, whose left-right divide is only temporarily invisibilized by the opposition between supporters and opponents of independence. Beyond the shift from monarchy to republic, in other words, it is highly unlikely that the political expectations raised by the posters would be realized after independence in the short- or even medium-term.

On the other hand, Catalonia has witnessed intense debates about feminism, ecology and a solidary economy and a growth of related practices in all these areas, apparently giving some validity to the expectations. However, none of this has been particularly impeded by any supposed Spanish domination and oppression. In contrast, similar practices have been developed in other parts of Spain, even though not everywhere with the same intensity. ${ }^{10}$ Thus, and here we arrive at the third key characteristics of the independentists' discourse, the claim for sudden and radical progress after the declaration of independence is based on the attempted annihilation of the recent past and of lived experience. We can illustrate such use of the past by one particularly telling example.

The Assemblea Nacional Catalana (ANC) is a non-governmental organisation, founded in 2012, the main objective of which is creating the social conditions for Catalan independence. It supported and even pressured the Catalan government in its unilateral course towards this aim. ${ }^{11}$ In December 2017, shortly before the Catalan elections on 21 December, it published a call to participate in the vote in the form of a newspaper advertisement (for instance, in the neighbourhood newspaper L'Independent de Gràcia of 15 December 2017), based on a distinction between past, present and future presented in three columns of decriptions under themes such as "regime", "censorship", "justice", "language" among others. The present is described by emphasizing the impact of the suspension of Catalan autonomy, issued by the Spanish government after the unilateral declaration of independence at the end of October. The text uses highly critical, in many cases exaggerated terms such as "censorship" of public media, lack of "separation of powers", "political prisoners", "linguistic model threatened". In turn, the future is characterized in bright terms such as "participatory democracy", "freedom", "linguistic immersion", all to be reached by a Catalan state with all competences to be created after the elections. The striking element of the description of the future is that all those features, except the creation of the Catalan state, exist in Spain or are being freely debated among the political forces. But the reader is not invited to arrive at this insight because the present is defined as the time of suspension of Catalan autonomy. In turn, the past is not the period immediately before this suspension of autonomy but the Franco regime. Under the general heading of the advertisement "One step forward or forty years back", it is suggested that without the creation of a Catalan state a return to the conditions under Franco, rightly described with terms such as "dictatorship", "control of the press", "political prisoners", "prohibition to use Catalan in public", is imminent. Thus, the period from Franco's death in 1975 to September 2017 is missing from the picture, precisely the period of democratic Spain during which Catalan autonomy flourished. It requires a careful look to recognize that hardly anything of what is promised for the

10 After the last municipal elections, of 2015, both Barcelona and Madrid saw the formation of a municipal government based on alliances of urban social movements.

11 At the time of writing, in late October of 2018, the organization stands out for its persistent urging towards unilaterality, devoid of any self-critical element regarding the experience of the past year. 
future was not already reached during the period just before the present, which the readers are supposed to forget or neglect even though most of their life experience was made during it. Furthermore, the fact that the suspension of autonomy was triggered precisely by the attempt at creating an independent Catalan state appears from sight. Over the past decades, historians have investigated the many ways in which reference to "the past" has been used to re-interpret the present, but is difficult to encounter another "use of the past" that so bluntly tries to annihilate the very recent past. ${ }^{12}$

Moving to the other side in the conflict, in turn, one sees immediately that the constitutionalists' praise of the present is the counter-strategy to the oblivion of the present - or: very recent past pursued by the independentists. As such, there is no need for a more elaborate view on history for the constitutionalists. It is sufficient for them to see current democracy as a historical accomplishment that determines both the legality and legitimacy of all further actions. All one can detect is a light touch of modernization theory according to which human history is on a steady path of normative progress. "Democratization" is one component of this path, and the end-point in this respect is "consolidated democracy", a stable political situation in which all normative requirements for rights and freedom are met and which has at its disposal all the means to secure these requirements for the future. Former Spanish prime minister Mariano Rajoy indeed used the term democracia asentada ("settled democracy") when explaining why Spanish institutions can successfully and convincingly handle the Catalan conflict (europapress 2017). This attitude is conservative, as it tends to suggest that not much more than what has been achieved in the present can at all be achieved (see Hirschman 1991). But what is more problematic is that it is complacent. It is so assured of the lasting nature of the political accomplishments that it tends to underestimate the constitutive fragility of democracy (see Karagiannis 2016). And such self-assurance arguably led Rajoy to misrecognize the challenge that Catalan independentism entailed - and, one should, makes his government a prime responsible for the escalation of the conflict.

\section{Conceptuality: how to connect situations across time}

Let us now turn the question around and consider how concepts have been deployed in the conflict to connect situations across time and, thus, to enhance certain interpretations at the expense of others. Rarely has a political conflict so much focussed on key concepts, launched without explicit context, thus apparently abstractly, but at the same time suggestive of a certain interpretation. This use was predominantly promoted by the independentists; the constitutionalists were at best reactive - and very often did not have any response at all.

The concepts that were made central were "democracy", "rights" and "freedom", without any doubt key concepts of modern political thought and "essentially contested" (W. B. Gallie) at the same time. Series of posters with a single of those terms each were put up across Catalonia, not adding any further text, thus suggesting that their meaning was obvious. At a closer look, conceptual connections also existed. Thus, "democracy" was linked with "we shall vote"; "right" was specified as "right to decide" and "right to self-determination"; "freedom" with both of the other conbcepts and, somewhat later, with the call for "freedom for the political prisoners". At a somewhat secondary level, concepts such as "revolution" and "rule of law" were also mobilized. In what follows a brief analysis of some of the conceptual moves will be provided.

Let us start with the concept of democracy. For constitutionalists, practicing democracy means the application of the existing rules, which include free and equal universal suffrage for adult citizens,

12 Analysis by Kostis Kornetis, presented at the workshop "Histories against histories" at the University of Barcelona in February 2018, devoted to this question, also emphasized "the return of Franco" as a key theme of the independentists' discourse. 
accompanied by electoral rules that specify the boundaries and competences of the polity and subpolities, the attribution of parliamentary representation according to the vote, and the formation of government from parliamentary proceedings, as well as freedom of expression and of the media. Details of the specifications are frequently debated in Spain, as elsewhere, but there used to be agreement that changes to the rules should be emerging from the application of the existing rules.

The Catalan government and parliament broke this consensus in September 2017. They did so on the basis of different assumptions about democracy. And they could do so against the background of the indignados movement, also known as the $15-M$, the 15 May 2011 movement, one of whose key slogans was "Real democracy now", suggesting that Spain was not at this moment a real democracy. Independentists from then on started to assume that democracy is fundamentally expressed in the vote only, and furthermore that the most explicit form of the vote is a referendum in which the people directly expresses its will. This is not necessarily in contradiction with a general concept of democracy, but it entails a neglect of the variety of ways in which the commitment to democracy can be interpreted in favour of a single one that is considered superior. Furthermore this understanding downplays the significance of the specification of application rules for the democratic commitment. ${ }^{13}$ The initial attractiveness of this understanding is its idea of immediacy: the people seize back their power to decide, which had been usurped by an oligarchy or political class. By implication, though, the neglect of accompanying rules leads to a highly majoritarian concept of democracy, reminiscent of Tocqueville's notion of the "tyranny of the majority". ${ }^{14}$ Once a referendum is held or once a parliamentary majority is in place, all further political action follows from the referendum outcome or is determined by the majority. Notions of constitutional constraints, "checks and balances", minority rights, as they have been developed during the history of modern democracy, are cast aside without further consideration.

To make the understanding work in the Catalan case, though, immediacy is not enough, and this is where we see the above-mentioned tension re-emerging. The understanding needs to be underpinned by a notion of the Catalan "people" or "nation" who seizes back its power - and this not from a Catalan political class as it would be in more common approaches to "direct democracy", but from Spain. Thus, beyond the appeal to radical democratic immediacy, there is also an appeal to something essentially Catalan: the majority cannot but be a majority for Catalan independence and self-determination, since this is what "the Catalan people" wants. ${ }^{15}$ One of the ironies of "the process" was that this claim mobilized voters in favour of continuity within the Spanish polity, who in earlier Catalan elections had by and large accepted the hegemony of moderate Catalanism. Unlike at any moment before, thus, Catalonia now appears politically divided between two opposed blocks of about equal size, one for and the other against independence.

Based on this understanding of democracy, independentists claim for themselves rights - rights that they see as superior to the Spanish and Catalan laws that they have very consciously been breaking. With regard to the concept of right, that which I call here tension or ambiguity again emerges in very clear-cut form. The above-mentioned assumption of a "Catalan people" as a political subject leads to the claim for a "right to self-determination" for this subject, along the lines of what I have described before as the case for national liberation (see, for instance, López 2017). This claim is indeed very straightforward, since the right to self-determination is a collective right that is rather clearly, though not often explicitly, established in international and constitutional law. To support a claim for independence/secession, it stands in tension with the state right to territorial integrity and demands not only the existence of a distinct collectivity, but also the fact that this collectivity is

13 There is a tension between discourse and practice. The independentists see no problem in using the electoral law that assigns them a majority of seats in parliament without having obtained a majority of votes in the election.

14 This majoritarian understanding could be seen, in larger perspective, as a rejection of the technocratic understanding of democracy as being legitimated by efficiency (Majone 1988; Scharpf 1999), but there is no space here to go into such analysis.

15 Rather exactly in the way in which Claude Lefort (1972) described the imagination of "le peuple-Un". 
being oppressed by another collectivity or a regime (see, e.g., Council of Europe 2000).

Independentists have been claiming this right all along the duration of "the process" and have appealed to all possibly relevant international bodies and organisations. But the verdict has been unanimous: the conditions to invoke this right do not exist in the Spanish-Catalan case. Catalonia is part of a decentralized democratic polity that not only safeguards minority rights but provides for Catalonia a high degree of self-determination and capacity to protect and support its language and culture. The defeat on this count has, though, not prevented independentists from repeating the claim, even in the new political constellation after government changes in Spain and Catalonia in the spring of 2018.

Nevertheless there is awareness of the problem within independentist debate. To counter the objections, a supposedly more general "right to decide" has been invoked that apparently requires neither a distinct people nor oppression. Just as in the case of the new understanding of democracy, this notion works with an immediate attractiveness. It claims an aura of self-evidence in times of a supposedly universal commitment to human rights and democracy. In our liberal societies, in particular, who would want to be against a right to decide? This right appears to be built on the model of individual rights, suggesting an extension of the notion of personal freedom, not least on the highly visible "pro choice" slogan in the struggle over the right to abortion. But in contrast to abortion, the "right to decide" is not intended as a right of individual human beings. It works with an empty, abstract notion, but is meant to refer to collectivities while avoiding to indicate who those collectivities are and what defines them. It was thus begging the response, in form of political comedy, of claiming the right to decide for "Tabarnia", a neologism for the territory around the urban centres of Barcelona and Tarragona in which the support for Catalan independence is low.

In the more sophisticated parts of the independentist debate, the tension between the "right to selfdetermination" and the "right to decide" is well recognized and critically debated. It is even noticed that the abstract "right to decide" draws on libertarian political self-understandings that ultimately undermine any notion of collectivity and, thus, would turn out to be self-defeating for independentism (Torbisco Casals 2017, 213-19). Nevertheless both terms keep being used in parallel and largely interchangeably. This has the advantage of, at the same time, referring to something substantive that is behind the claim to independence, namely a "Catalan people", and making use of the apparently more timely imaginary of ever further extensions of rights and freedoms. ${ }^{16}$

Freedom is indeed the concept that completes the independentists' triangle of abstract concepts that supposedly support their case in a self-evident way. It is the one that is least specified and acquires meaning only in combination with the claim to democracy as collective freedom and to rights as safeguards for freedoms. After at the end of October 2017 Catalan autonomy was suspended and the leading members of independentism were accused of rebellion, sedition and embezzlement of public funds and some of them were imprisoned, the concept of freedom was specified as "freedom for the political prisoners". This call is now to be seen all over Catalonia, supported by yellow ribbons and other yellow-coloured signs. It marks a new phase of the campaign, underlining the supposed repression by Spanish authorities and violations of human rights of independence activists. Again, the paradox emerges that the political campaign is reduced from "freedom for Catalonia" to "freedom for the political prisoners", whereas those politicians have only been imprisoned because they are accused of illegal actions in pursuit of the initial broader objective.

Nevertheless this discursive strategy bore immediate fruit in international debate. For current purposes, it is useful to discuss one example to show the degree of conceptual confusion that was

16 For an expertise on the "right to decide" provided at the request of the Catalan government in 2017, see Levrat et al. 2017. "Despite being composed of several law professors", as the authors themselves say (p. 10), the expert committee focused on what they consider questions of legitimacy rather than legality. 
created by the deliberate play with conceptual ambiguities typical of the current situation. On 31 October 2017, an open letter to the President of the European Commission, Jean-Claude Juncker, and the President of the European Council, Donald Tusk, titled "Upholding the rule of law in the European Union", was published by, as the letter says, "scholars, politicians, public intellectuals and members of the European Parliament". ${ }^{17}$ The letter makes a distinction between "rule-by-law", referring to any procedurally validated law, and "Rule of Law", which entails normative commitments, namely the "safeguarding of fundamental rights and freedoms".

Preceding this distinction, the text enumerates legal actions taken by the Spanish judiciary that are seen as violations of the Rule of Law in the above sense. Thus, it characterizes a referendum as an expression of the freedom of speech and of assembly and considers its outlawing as a violation of those principles. But the referendum decided by the Catalan parliament was explicitly intended as a voting and decision procedure, not as an expression of freedom of opinion, and it was declared illegal as such. Subsequently, the text refers to "repressive actions" with little specification. There is no mention of the fact that the prevention of an illegal act from happening - in this case, the socalled referendum - is the legitimate task of law-enforcement agencies in societies governed by the Rule of Law. ${ }^{18}$ The same applies to the police action on referendum day, which is denounced as "excessive" or "disproportionate". While this is open to debate, there are legal institutions in Spain which can investigate such claims according to the normative commitments enshrined in the Rule of Law, as understood in the letter. (This has indeed happened in the meantime.) Finally, the arrest of the presidents of the two main pro-independence organizations, Jordi Cuixart of Omnium Cultural and Jordi Sànchez of ANC, is denounced as violating "the right to peaceful public manifestation". Cuixart and Sànchez were involved in action preventing police and judicial agents from performing their task - no one raises any doubts about this. Their action can be understood as civil disobedience, but civil disobedience has always been recognized by its practitioners as infractions of existing law and was thus expected to be subject to persecution. (We come later to the question of higher principles that may justify civil disobedience.) Whether Cuixart and Sàchenz's actions amount to "sedition" according to Spanish law, as the prosecution claims, is under investigation and not yet determined. But it is important to underline that it is eventual illegal action, not the voicing of an opinion, that is being investigated.

In sum, despite arguing with supposed facts, the letter fails to identify any instance in which Spanish judiciary institutions were violating the "Rule of Law" in their actions against the pursuit of the referendum and the declaration of Catalan independence once those had been declared illegal. Strikingly, the account of facts given in the letter starts with the $1^{\text {st }}$ of October, the day of police intervention against the illegal referendum. It completely neglects the fact that the Catalan parliament passed the two laws on the $6^{\text {th }}$ and $7^{\text {th }}$ of September that violate both the Spanish Constitution and the Catalan Constitution (the Estatut), exactly those documents in which the normative principles of the Rule of Law are enshrined in Spain and Catalonia. It is these events that are the violations of the Rule of Law in Spain and that triggered the current controversy, not the

17 At the time of writing, the letter is still available on the internet and can be found as: LETTER-TUSK-JUNCKERFINAL1.pdf, last accessed 14 August 2018.

18 The eminent legal theorist Ulrich K. Preuß (2018) suggested that there was no need and not even any legal possibility to act against the referendum. Once it had been declared illegal, so the argument went, the referendum could no longer happen and any preparation for it was nothing but citizen action without effect and as such no longer objectionable. Preuß even evokes Don Quijote and thinks that the Spanish judiciary was fighting phantasmas. But even if one considers the referendum and the subsequent unilateral declaration of Catalan independence as performative acts that require authoritative validation, as Preuß does, this does not make them disappear if not validated. The law imposed by, say, a criminal association - say, to use a stereotypical reference, in a favela of Rio de Janeiro - is not authoritatively validated, but nevertheless in force. The issue is even more complicated in the Catalan case as the Catalan government possessed some formal authority, even though not a constitutionally sufficient one, and thus could convey the idea that its acts were valid. (In German, such authority is called Staatsgewalt, which could literally be translated as state violence, even though it is conventionally rendered as state authority or state power.) 
subsequent actions of Spanish judiciary institutions. In other words, the text only refers to legal actions that were taken in response to the violation of the Rule of Law by the Catalan government and parliament. Thus, it fails to explicitly recognize that these are actions meant to restore the Rule of Law. The signatories of the letter, most of whom are far from the events, succumb entirely to the conceptual confusion deliberately sown by independentism. For our concerns, it is significant that numerous eminent social and political philosophers are among them, such as Etienne Balibar, Seyla Benhabib, Judith Butler, Nancy Fraser, Christoph Menke, Philip Pettit, Boaventura de Sousa Santos.

\section{Social movements and political institutions}

This latter fact begs further questions, not least the one how it is possible that this confusion arises and, to some extent, persists. The letter to Juncker and Tusk is useful to approach an answer to this question because it reasons exclusively in terms of law and philosophy of law and avoids reference to social, political, cultural or historical phenomena. Thus, it does not bring in any argument about power, domination, oppression of Spain over Catalonia, which, while potentially valid, would indeed fall on deaf ears with the presidents of the European Commission and the European Council, not least because they lack the tools to address such issues. With its exclusively legal emphasis, at the same time, the letter lays bare the underlying logic of the reasoning. To repeat: the letter denounces a number of actions by Spanish institutions that are clearly legal, that is, in line with existing law ("rule-by-law", as the letter puts it) as violating "fundamental rights and freedoms", but fails to mention that these actions also - to say the very least - defend fundamental rights and freedoms, such as the legal equality of all Spanish citizens, the protection of citizens from usurpation of power, the stability of the framework of legality. Such unqualified denunciation reveals an underlying attitude that tends to see all use of public authority as freedom-endangering. Or in other words, it confuses authority with authoritarianism.

This is a phenomenon that can be more frequently observed in recent decades, more on the left of the political spectrum, but by far not exclusively so. It is closely related to a global ideological constellation in which the reference to "human rights and democracy" has become omnipresent, something that maybe spells progress in the history of humanity. But a consequence of this constellation is that anything that claims to be in favour of "human rights and democracy", or $a$ forteriori against violations of these principles, does not seem to require any further supporting evidence. But at the same time, the points of reference for these principles are fading away. Human rights need an authority to secure them; and democracy needs a defined collectivity that selfdetermines its ways of living together. The historical point of reference was the nation-state. Today, though, so-called humanitarian interventions can be done by external powers; and collective action within a nation-state often determines very little.

The nature of the self-determining collectivity being unclear, "democracy" as an institutional framework for freedom, to paraphrase Hannah Arendt, tends to be replaced by "democratization" as an unfolding process. Any large number of people going peacefully to the streets and claiming some right that they are being denied or some abuse they suffer from an authority tend today being seen as "democratizing", helped by the instant global spread of pictures and the news-clip form of reporting. For Western observers, this is always more easily done when the protest takes place in non-Western societies that can be accused, mostly without much detailed knowledge, of lacking democracy. Catalan independentism sings to the tune in perfection by incessantly portraying itself as democratic and non-violent, understanding well that such commitment is indeed almost a general condition for successful social movement activity in our time. ${ }^{19}$ In turn, that is also why it

19 The so-called Committees for the Defence of the Republic (CDR), which were created during 2017, act at and beyond the borders of these principles by spraying offices of constitutionalist parties and private residences of politicians and judges, for instance. But their actions are immediately, though mildly, criticized by more central 
was important to portray the Spanish state as authoritarian, as most visibly the former trainer of Football Club Barcelona, Pep Guardiola, did at a widely broadcast demonstration (see, for instance, Ara 2017).

To object to interpreting such social movement activity in this way is difficult because, clearly, there are always real concerns; people are not going to the street easily - especially not in circumstances, unlike the Catalan ones, where they risk suffering serious harm. But their key concern may not necessarily be democracy; addressing their concerns may not necessarily make a society more democratic; and, often most importantly, if a movement gains power this is not necessarily a victory of democracy. But we are hampered in our understanding of the new phenomena by a long-lasting intellectual tradition that sees social movements conjointly as contesting established power structures, aiming at democratizing institutions and bringing about a progressive transformation of societies. This tradition goes back to the interpretation of the European workers' movement as challenging the oligarchic reign of the bourgeoisie by representing the universal interest. When the workers' movement became increasingly integrated into Western societies after the Second World War, analysts looked for "new social movements" as expressing the new "central conflict" of societies that were no longer based on industry but had turned "post-industrial" (these very explicit terms are Alain Touraine's, but the perspective was more widespread). Even though that search turned out unsuccessful, the tendency to identify social movements with justified contestations of power and progressive political claims persists. Contestation, mobilization and conflict are without doubt key phenomena that bring about socio-political change. But careful assessments of the societal situation in which they emerge and the forces that they mobilize are required to understand the nature of the changes these phenomena are aiming at and - which is not the same - those that they are likely to bring about, in particular under current circumstances (for a more detailed reasoning, see Mota and Wagner 2019, especially chapter 10).

With regard to the Catalan conflict, a closer look makes it very difficult to sustain the notion that independentism is a liberating, democratizing social movement. Much of the appeal that "new social movements" had during the 1970s was derived from the view that they were spontaneous expressions of protest against injustice or oppression. We have become accustomed to think of our societies as composed of individuals; and that is why the apparently spontaneous going to the street of the multitude comes to be interpreted as a liberating, democratizing phenomenon. But Catalan independentism is created from existing organizations and mobilized by the power of those organizations. Not political parties but "civil society organisations" such as the ANC or Omnium Cultural have organized the large rallies on each 11 September since 2012, have called people out to defend the organization of the vote on 1 October 2017 and to picket small shops, mostly run by immigrants, at the standstill operation in early October. Furthermore, these organisations are closely related to government power. Former Catalan president Puigdemont organized the key government operations not with his cabinet but with a handful of people including the leaders of ANC and Omnium. Rather than a social movement, the independentism of "the process" has been a concerted effort by organized groups to gain institutional power through mobilizing street-level activity. Reinterpretation of political concepts has been a key component of this strategy. Returning to George Orwell's 1984, the Big Brother is on this occasion not an all-powerful state, it is a highly organized and mobilized section of society.

To understand why such a strategy suggested itself, and also why it has been partially and temporarily successful, we have to return to the ambiguity and tension between an abstract, atemporal interpretation of key political concepts, on the one hand, and a historically saturated one, on the other. The major social transformation that started during the 1970s had led by the 1990s to the assumption that social life underwent parallel tendencies of globalization and individualization

independentist actors, carefully trying to both keep up the image of non-violence and avoid alienating important supporters. 
(see Wagner 1994). These supposed tendencies lent themselves to a political interpretation in terms of the abstract commitment to human rights and democracy. Human being were seen as individuals without strong social bonds, and democracy was seen as a set of procedures rather than as the commitment of specified collectivities to self-determination. We have called this re-interpretation elsewhere the erasure of historical time and of meaningful socio-political space (see Wagner 2015). ${ }^{20}$

In the course of the last decade, though, and in Europe maybe particularly after the financial crisis of 2008, discontent with these tendencies was growing. As a response, attempts were made to resituate oneself and one's communities in time and in space. In many such cases, often called "new nationalism" or "new right", these responses appeared as attempted restorations of preceding political forms, including conservative values and distrust in openness and democracy. From a standard liberal-democratic perspective, the problem was that such responses addressed recognizable socio-political problems but did so in normatively unacceptable ways. From that angle, it was difficult to recognize that globalization and individualization did not necessarily enhance conditions for liberation and emancipation, or at least not exclusively so, and that, in turn, retrieval of historical time and meaningful socio-political space can do so.

Catalan independentism expresses this ambiguity. It emphasizes the need to protect Catalan language and culture and aims to set up a polity of the Catalans in separation from the Spaniards. This can be read as an attempt to retrieve historical time and meaningful space. However, it also presents itself as liberal, democratic, open-minded and, in some of its currents, at aiming at a progressive transformation of society. In many instances, it is clear that this ambiguity is strategically played with. But for numerous independentists the two aspects go easily together and they are unaware of the profound tension.

\section{The case for independence: the instituted and the instituting}

With the preceding reflections we have entered into a discussion of the substantive claims of independentism, about which little had been said before, beyond the notion that the Catalans are oppressed as Catalans and the expected advent of a socialist-feminist-ecological republic at the moment of Catalan independence. Indeed, there is very little of a common substantive core of independentism. This can be gathered from the fact that the independentist government that was formed after the September 2015 elections proposed very few substantive policies until its destitution in October 2017, beyond preparing for the declaration of independence. The same is true for the current government that was formed, after a long negotiation process, as the outcome of the December 2017 elections.

In conversation, independentists often get very defensive when being asked about substantive claims. They would need to give an answer to the question what would be improved by the creation of an independent state. An end-point of such discussions is either a forceful "we want to get rid of Spain, and we'll do so" or a somewhat resigned "I can't see why Catalonia should not be independent". The former statement expresses a voluntarism beyond reason, but the latter points to a decisionism that is worth exploring further, since it asks for reasons.

Looking at the political map of Europe, there is indeed no compelling reason why Catalonia could not be an independent state. It has the size of many of the middle-level member states of the

20 There is sufficient evidence to consider this transformation as a global phenomenon, even though further comparative investigation is needed. In detail, the experiences and their interpretations vary considerably. For an impressive account of the experiences in India and, in particular, in the city of Delhi during the 1990s and early 2000s, see Dasgupta 2014. 
European Union such as Austria, Finland or Greece, a quite vibrant and rather diversified economy, good institutions of public health and education, including higher education, and institutions of selfgovernment at the level of municipalities, provinces and the Autonomia itself. To point out these features is important, but such reasoning looks at functionality only. Furthermore, it is a decontextualized reasoning, analogous to the one about abstract democracy, rights and freedom. This, it emphasizes one side of the conceptual ambiguity and downplays the other. Catalonia has a long entangled history with the rest of Spain, which does not only concern high intra-Spanish migration, a division of social labour, and a unified public administration. For our purposes it more important that it has a history of democratic commitment to common political institutions, as pointed out earlier.

This fact used to be recognized by independentism as long as the objective was to hold an "agreed referendum", that is, agreed with the Spanish political institutions, on the often mentioned model of Québec and Scotland. This idea is based on a notion of the commonality of the existing political framework. Thus, it aims at agreement with the Spanish institutions and also requires openness as to the terms of the referendum (within Catalonia only or across Spain; consultative or binding; the nature of the questions to be asked). But any kind of referendum was persistently denied by the Spanish governments under Mariano Rajoy. In purely procedural terms, the rejection of a referendum meant the end of debate for the time being. In this direction, the only possible further step for the independentists would have been working for a change in the Spanish political institutions, such as change of parliamentary majorities, change of government, change of the constitution. However, independentism decided not to pursue this path and opted instead for unilateralism, changing its discourse towards claiming the right to a referendum, rather than an agreement, based on some version of the "right to decide" or the "right to self-determination", as discussed above. ${ }^{21}$ This, though, meant no longer accepting the commonality of the existing political framework.

Thus, "the process" stepped out of anything that could be discussed in standard procedural terms. Or more precisely, this decision defined the conflict in exceptional terms while aiming to hold the Spanish institutions to dealing with it on standard procedural terms - the "Rule of Law". Rather than a state authority decreeing a state of exception, a regional political power-cum-social movement created a situation of exception. As we have seen, this situation of exception has been dealt with by opposing the standard democratic procedures and their underlying political philosophy with the increase of conceptual ambiguity attempting to undermine the legitimacy of existing statehood and mobilizing new normative claims. Considering this opposition a rather unsatisfactory outcome, we will make a brief attempt to see what more can be said about such situation in politicophilosophical terms.

The first step to be made is to allow for such a possibility to arise. If democracy is understood as collective self-determination, then the term refers to more than a mere form of government. It must include the capacity for self-transformation in the light of new situations (Rosich and Wagner 2016). The need for self-transformation, furthermore, can go beyond that which the existing institutional framework permits (such as the rules for changing the constitution). Having said this, such an exceptional situation also places demands on those who ask for fundamental change. The requirements of justification are higher than those for policy change, legal change or even constitutional change within the existing framework.

At this point, the distinction between instituting moments and instituted moments, made by Cornelius Castoriadis (e.g. 1997), is useful. Castoriadis was interested in the creative action of

21 The references to Québec and Scotland continued, but it was overlooked that these referenda were based on indeed agreements not a right and that they were the exceptions among many more cases in which central governments rule out any such possibility from the start. 
instituting society and indeed underlined the capacity for self-transformation as characteristic for democratic societies committed to autonomy. He was highly critical of current European societies, whom he characterized as "liberal oligarchies", for having abandoned the commitment to autonomy and the capacity for self-transformation. The insistence of some Spanish politicians that the "transition" from Francoism to democracy was an accomplished success and is in no need of further consideration can be read as a confirmation of Castoriadis's view. But Castoriadis also underlined that every society needs to be instituted, to be based on some kind of a stable and common social imaginary. Thus, he did not give preference to the instituting over the instituted moment. Rather, we can take him to be asking for the relation between the instituted imaginary and the one that is meant to replace it in an arising instituting moment.

In other words, for a political imaginary to be used for creating an instituting moment, it has to address critically the existing institutions. Following Luc Boltanski (2009), one can distinguish between two forms of critique. The first shows that institutions do not perform that which they themselves are meant to perform. It aims at changing the existing institutions in such a way that they achieve what they are meant to achieve. The second critique shows that institutions do something that should not be done. It aims at replacing these institutions by others that do what should be done. Even though there is no space here to show this in detail, the independentist critique of Spanish institutions, whenever it is somewhat concrete, is largely of the former kind. No substantive radical critique is recognizable that would demand replacing the Spanish institutions by others set up for different purposes.

This lack notwithstanding, a revolutionary self-understanding is rather widespread among independentists, especially those of the younger generation. Repeated reference is made to the French Revolution, and it is suggested that what is going on in Catalonia is something akin to the French Revolution. Partly, this view is based on the rather erroneous assumption that the French Revolution initiated the processes of national liberation and nation-building across the globe. But the reference also serves to emphasize the radical novelty that Catalan independence is about to create, the enormous dimension of intended change. This is in striking contrast with the substantive emptiness of "the process". This author is not inclined to agree with Richard Rorty (1989) that political thought needs no further "conceptual revolution", but clearly no trace of it can be found in Catalan debates over independence. There is no widening of normative horizons, as it was characteristic of the French Revolution and also of subsequent socialist revolutions.

\section{Other interpretations}

With the above, I have aimed to enhance the understanding of the Catalan crisis by providing a contextual analysis of the use of political concepts. In particular, I have shown how independentism tried to destabilize the prevailing meaning of key political concepts such as democracy, right, and freedom. It has succeeded in unveiling an irresponsable complacency among parts of the political elites about the coherence and stability of the prevailing meaning. But it has failed in suggesting new meanings that open up wider normative horizons for democracy, right and freedom. Even more, it has not even made a sustained effort to do so. Rather, it remained content with increasing ambiguity and confusion about the meaning of these concepts, driven by the purpose of achieving an objective that from an external view looks highly parochial. The Catalan independence movement is committed to non-violence, but it has operated through a radical attempt to destroy the conceptual basis for living together.

The preceding analysis, I hope, sheds more light on the conflict and also situates it more clearly in its global context. But focusing on the use of concepts, however, the analysis also has significant 
limits that at least should be mentioned. ${ }^{22}$ Significantly, the rather sober conceptual analysis above does not offer sufficient elements for understanding why a very large number of Catalans have strongly and persistently committed themselves to "the process", devoting enormous amounts of time and resources to it and often being deeply emotionally involved in it.

This lack cannot be remedied here, but a few remarks can be made to acknowledge it and to invite for further investigation. Starting out from the issue of affective involvement, it is striking to see how conversations that begin as political discussions regularly reach points at which references to emotions are made in the shape of argument. Without judging them, a few such moments can be mentioned: On the independentists' side, common emotions are anger about powerlessness and resentment about lack of recognition. During the most intense period of the conflict, in particular during September and October 2017, these emotions gave way to elation about something significant about to happen. On the side of those reacting to "the process", there is sadness about the destruction of social bonds and also disgust about dishonesty and deceit. Together, this emotional constellation creates what has widely been decribed as a social fracture in Catalan society - which tends to be denied or downplayed by independentists but strongly affirmed by non-independentists. While the topic of independence used to be widely referred to in everyday conversations, it is now being avoided and mostly addressed only among like-minded interlocutors.

Among independentists, especially the younger generation, there is a strong feeling of togetherness in self-created local contexts, reaching from cultural and sports associations to explicitly political groupings. ${ }^{23}$ While this may be more pronounced than in other societies, but not at all uncommon, in Catalonia this local embeddedness goes together with alienation from the larger, Spain-wide associations and institutions. Ironically, or maybe paradoxically, this divide may be exactly an effect of four decades of Catalan self-government rather than, as is claimed, by Spanish oppression. Whatever the causes, such alienation is an impediment for engaging in the democratic institutions that have rather consensually been created over the past four decades.

Against this background, the physical, bodily involvement in defending the illegal referendum on the $1^{\text {st }}$ of October by occupying the schools that served as voting sites and trying to prevent the police from entering comes to be lived as an experience of democracy. The event disrupts the boredom of living in an affluent society, a recurrent occurrence in the recent history of Western societies. And it does so by participating in something that is grander than one's personal life. ${ }^{24}$

Inserting these last observations into the context of the preceding conceptual analysis, an important democratic deficit in European societies becomes visible. It has nothing to do with the widely discussed "democratic deficit" of the European Union, since forms of participation are widely available. Rather, it is a deficit of democratic culture, namely the capacity to relate one's own experiences, passions and interests to the democratic institutions that have been co-created during the past. In what are likely to be harder times of the future, the fact that European societies have not sufficiently been able to develop such a democratic culture during the post-war and postdictatorship decades of relative affluence may reveal itself as the most important shortcoming. De-

22 There are common socio-cultural observations about attempts at explaining separatism such as the search of regional elites for institutional positions of power, the economic interests of affluent groups in society, the perception that an identity-providing culture and language are threatened, memories of past injustice and oppression. Focusing on political aspects only, we have deliberately left these aspects at the margin.

23 From within independentism, this feature has been characterized - and criticized - as a predominant youthful "scout" attitude that appears powerful in mass gatherings - as a "kumbayah coomunitarianism" - but fails to develop a sustainable political project (Martínez 2017).

24 For quite some time, independentism was discussed in Spain as having successfully created a narrative (un relato) of the conflict towards which constitutionalists had little to oppose. It appeared as if re-interpreting the world, regardless of the content of the interpretation, could change the world. But at the current stage the unfolding of the conflict rather shows that an interpretation without substance, as much as it may temporarily galvanize political energies, has little effect when confronting existing political institutions. 
institutionalization may often be an important prerquisite for political transformation. But maybe we are only beginning to see the consequences of ever more widespread de-institutionalizing political projects in existing democracies. These consequences are much more likely to favour the actual holders of political and economic power than those who, often in good faith, emphasize and criticize forms of power contained in democratic institutions.

\section{References}

Ara (2019). 11 June 2017; https://www.ara.cat/es/ot-serra-soberanismo-civil-efectivoreferendum 0 1813018857.html; last accessed on 24 October 2018.

Bassets, L. (2018). "Los maestros narradores del independentismo: medios, propaganda, redes", in J. Coll, I. Molina, and M. Arias Maldonando, eds (2018). Anatomía del procés. Clavos de la mayor crisis de la democracia española, Barcelona: Debate, 2018, 159-80.

Boltanski, L. (2009) De la critique, Paris: Gallimard.

Booth, J., and P. Baert (2017). The dark side of Podemos, London: Routledge.

Castoriadis, C. (1997) 'Fait et à faire', in Cornelius Castoriadis, Fait et à faire: les carrefours du labyrinthe V, Paris: Seuil.

Coll, J., I. Molina, and M. Arias Maldonando, eds (2018). Anatomía del procés. Clavos de la mayor crisis de la democracia española, Barcelona: Debate, 2018.

Council of Europe, Venice Commission (2000) Self-determination and secession in constitutional law, Strasbourg, 12 January; http://www.venice.coe.int/webforms/documents/?pdf=CDL$\underline{\mathrm{INF}(2000) 002-\mathrm{e} ;}$ last accessed 14 August 2018.

Dasgupta, R. (2014) Capital. The eruption of Delhi, New York: Penguin.

Europapress (2017) https://www.europapress.es/nacional/noticia-rajoy-agradece-senado-apoyopsoe-cataluna-pide-no-entrar-discrepancias-menores-20170912174344.html, 12 September 2017, accessed on 24 October 2018.

Gamper, D., (2018). "Ambivalences of populism: the case of Catalan independentism”, Social Science Information, vol. 57, no. 4, *_*.

García, L., (2018). El naufragio. La deconstrucción del sueño independentista, Barcelona: Ediciones Península, 2018.

Gascón, D. (2018). El golpe posmoderno, Barcelona: Debate.

Hirschman, A (1999) The rhetoric of reaction, Princeton: Princeton University Press.

Junco, J. Á, and A. Shubert (2018) Nueva historia de la España contemporánea (1808-2018), Madrid: Galaxia Gutenberg.

Karagiannis, N. (2016) 'Democratic surplus and democracy-in-failing: On ancient and modern selfcancellation of democracy', Rosich, G., and P. Wagner, eds. The trouble with democracy, Edinburgh: Edinburgh University Press. 
Koselleck, R. (1979) Vergangene Zukunft, Frankfurt/M: Suhrkamp.

Lefort, C. (1972) Essais sur le politique, xix/xxe siècles, Paris: Seuil.

Levrat, N., S. Antunes, G. Tusseau and P. Williams (2017). Catalonia's legitimate right to decide. Paths to seld-determination, Geneva: University of Geneva, https://www.unige.ch/gsi/files/9315/0461/7440/CATALONIAS_LEGITIMATE_RIGHT_DECIDE. pdf, last accessed on 24 October 2018.

Lopéz, Jaume, "The right to decide: a right of the $21^{\text {st }}$ century", in: Kraus, Peter A., and Vergés Gifra, Joan (eds), The Catalan process. Sovereignty, self-determination and democracy in the $21^{\text {st }}$ century, Barcelona: Institut d'Estudis de l'Autogovern, 2017, 121-37.

Majone, G. (1996) Regulating Europe, London: Routledge.

Martínez G. (2015) “Cataluña jamás será independiente”, Interview with Alfons López Tena, CTXT, 12 September, http://ctxt.es/es/20150909/Politica/2187/Catalu\%C3\%B1a-Lopez-Tena-Masindependencia-Catalu\%C3\%B1a-Espa\%C3\%B1a.htm, last accessed 14 August 2018.

Mota, A., and P. Wagner (2019) Collective action and political transformations: the entangled experiences in Brazil, South Africa and Europe, Edinburgh: Edinburgh University Press (forthcoming).

Orwell, G. (1949) 1984. London: Secker and Warburg.

Orwell, G. (1938) Homage to Catalonia. Secker and Warburg.

Preuß, U. K. (2018) "Spanische Tragödie. Kataloniens Kampf geht nicht um Freiheit, sondern um Identität”, verfassungsblog.de, 3 April 2018, last accessed on 14 August 2018.

Rorty, R (1989) Contingency, irony, solidarity, Princeton: Princeton University Press.

Rosich, G., and P. Wagner (eds) (2016) The trouble with democracy. Political modernity in the $21^{\text {st }}$ Century, Edinburgh: Edinburgh University Press.

Scharpf, F. (1999) Governing in Europe: effective and democratic?, Oxford: Oxford University Press.

Torbisco Casals, N. (2017) "National minorities, self-determination, and human rights: a critique of the dominant paradigms in the Catalan case", in: Kraus, Peter A., and Vergés Gifra, Joan (eds), The Catalan process. Sovereignty, self-determination and democracy in the $21^{\text {st }}$ century, Barcelona: Institut d'Estudis de l'Autogovern, 195-225.

Wagner, P. (1994) A sociology of modernity, London: Routledge.

Wagner, P. (2003) "As intellectual history meets historical sociology. Historical sociology after the linguistic turn", in Handbook of Historical Sociology, G Delanty and E Isin, eds, London: Sage, 168-179.

Wagner, P. (2015) “Interpreting the Present”, Social Imaginaries, vol. 1, no. 1. 
Wagner, P. (2016) Progress: a reconstruction, Cambridge: Polity.

\section{Acknowledgement of funding}

Research leading to this article has been funded by the consortium Humanities in the European Research Area (HERA) for the project "The debt: historicizing Europe's relations with the 'South"' within the joint research programme "Uses of the past" (HERA-JRP-UP; 2016-19); and by the Russian Science Foundation (RSF) for the project "Varieties of modernity in the current global constellation: the role of the BRICS countries and the Global South" (2018-20; grant no. 18-1800236), based at Ural Federal University in Ekaterinburg.

\section{About the author}

Peter Wagner is Research Professor of Social Sciences at the Catalan Institute for Research and Advanced Studies (ICREA) and at the University of Barcelona, as well as project director at Ural Federal University, Ekaterinburg. His work aims to combine concerns of social and political philosophy with investigations in historical-comparative sociology to provide a critical diagnosis of the present time. 